\title{
Globalization and Global Welfare: A Critical Excursion
}

\author{
Jason L. Powell, Sheying Chen
}

\section{Introduction}

As we move into the global century, several aspects of social and economic life are changing and post-industrial shifts are unparalleled by virtue of the interconnectedness that brings together the corners of the globe. New technologies, new economic relationships, new social processes, and new political developments are all characteristics of globalization (Hudson and Lowe, 2004: 22) in a post-industrial age featured by information, innovation, finance and services. As the world has contracted, people's quality of life has changed regardless of where they live. In fact, the propagation of free market mindsets in emerging economies has created collective network connections with considerable good but pervasive inequalities as well (Walker 2001).

A fundamental aim of this paper is to argue that these changes are part of a economic transition to postindustrialism associated with risks and inequalities that shape human experience in the midst of a formidable global financial climate. There is an obvious tension with this. On the one hand, life expectancy, health statuses and per capital incomes are at an all-time high and many feudal practices have been relegated to the past (Phillipson, 2006). On the other hand, vast numbers of people struggle with poverty and significant pockets of poverty portend more than lack of income. Those living on the bottom of the socio-economic ladder labor under the burden of avoidable, lifestyle diseases, hunger and related maladies, not to mention myriad social risks (Turner, 2008). Those on the upper reaches of the same ladder garner disproportionate shares of the resources and are able to support comfortable lifestyles (Esping-Anderson, 1990).

\section{Global Poverty and Inequality}

Around the globe there are bona fide challenges facing nation-states as they attempt to adapt to the impact of modifications in morbidity, mortality, and need gradients among diverse segments of their populations. In the face of rapid demographic transformations resulting in fewer casualties from acute diseases, aging of populations and tumultuous economies, there are widening disparities and considerable quality-of-life inequalities within and between populations. In developing countries, China being one of the most striking cases in point but with parallels in a number of other developing countries the differential in per capital incomes of urban and rural people is at least a factor of three with virtually no top quartile wage earners residing in rural areas (Powell and Cook, 2010). There is a tangible rural to urban migration for economic gain, thereby creating even greater disparities as those left behind barely eke out subsistence livings.

It is impossible to overstate the risks of planetary poverty. More than 2.5 billion of the planet's population live on less than US $\$ 2$ a day and nearly a billion still have less than US \$1 daily (Chen \& Ravallion, 2007). As might be apparent, in this day and age poverty creates conditions in which rationality is redefined, nation-states struggle to control circumstances, not to mention criminality, low birth weights are ubiquitous, ill-health a fact of life, illiteracy 
rampant, malnutrition commonplace, environmental degradation seen as the cost of doing business, and notions of social justice are brought face-to-face with priorities said to have greater standing (Beck, 1999). Focusing on the extent of the disparities for just a moment: not only is there asymmetry but real immiseration as well - only about five percent of the world's income is earned by the poorest $40 \%$ of its people (Estes, Biggs and Phillipson, 2003).

According to the 12th Annual World Wealth Report (2008), the wealth of people around the world with more than US \$1 million in assets grew faster in 2007 than the world's economy. The world's economy exhibited a 5\% gain in 2007; compared with a growth rate of over $9 \%$ among those with at least US $\$ 1$ million in assets. Furthermore, the average wealth of these high net worth individuals (HNWIs) climbed to over US \$4 million, exclusive of their residence. Interestingly, the greatest growth among HNWIs occurred in Eastern Europe, Latin America and Asia led by Brazil, Russia, India and China. When the "mass affluent" population (those with less than US \$ 1 million but with substantial assets nonetheless) is added to the picture, the result is that the richest 20 percent of the world's population controls more than $75 \%$ of its wealth. In the past few decades there has been some striking gains among a relatively small percentage of the world's population (approximately 10 million out of 6.7 billion people can be classified as HNWIs) who are tapped into robust gains and wealth generation strategies (Annual World Wealth Report, 2008). The ascendancy of those forces concentrating high net worth wealth and capital accumulation among a narrow upper-crust is also capable of producing abject poverty among other segments of the population (Arias and Logan, 2002:197; Jessop, 2002). It is the richest 1 percent of wealthy outliers who are benefiting from speculation and the deregulation of commerce and free trade (Powell and Cook 2010).

Some estimates conservatively place the gap between the richest and poorest nations at an all time high of more than 50 to 1 (Clark, 2007). Even with the stalling of mature economies, the gulf between the most advantaged and the most disadvantaged in developed countries is no less dramatic; factor in the impact of gender, ethnicity or other social impediments and the complexity intensifies as formidable inequalities shape well-being (Powell and Cook, 2010). The disparities extend well beyond vital income differentials to quality of life issues, education, structured dependencies or social exclusions resulting from policy decisions (Townsend, 2007). Navarro (2007) and others add their voice to Peter Townsend's assertion by noting that escalating differentials can be attributed in no small part to interventionist strategies adopted and endorsed by national governments. Not surprisingly, as a consequence of the richest segments of the population having far greater assets and control over their lives, they feel they have more in common with their counterparts in other regions than they do with their less affluent opposite number in their own regions (Hoogvelt, 1997). Cross-cultural comparisons are extraordinarily valuable in helping lay out causal connections and for double-checking inferences. For example, the Organization for Economic Co-operation and Development (OECD) has a reliable cross-national comparative database of indicators of social policy expenditures in 30 member nations and their state sponsored social welfare provisions entitled Social Expenditures (SocX) in the period 1980-2003. It covers public expenditures for typical forms of welfare including old age, survivors, incapacityrelated benefits, health, family, active labor market programs, unemployment, housing and other social policy areas (education excepted). Shalev (2007) points out that if health and pension benefits are combined as a share of GDP, countries like Sweden rank at the top by devoting some $14 \%$ of its GDP to health and pension protections. Data for the period 1980-2001, the latest available on the OCED web-site, suggests that Germany expends about $8 \%$ and the United States and Japan about 4\%.

\section{Globalization and Reformation of Economic Power}

The proliferation of adjuvant ideologies evolving out of burgeoning free-market economies along with an accompanying diffusion of instrumental rationality, standardization, commoditization or secularism have become embedded in our thinking, challenging all other relational metrics of daily life. In the process, modes of interaction and standards of assessing relational status or personal worth are recast. In both developed and emerging economies the nature of work and the meaning of careers are also undergoing major reformulations. There is a global softening of labor markets linked to downsizing of local employment opportunities, redundancies, a spate of subcontracting arrangements, and an economic volatility abetted by technological innovations that chip away at employment security, wage or benefit packages bringing a degree of economic and existential uncertainty to greater numbers of people. Of course such changes are not distributed evenly across all forms of employment, further exacerbating inequalities. It should also be stressed that adversity does not appear to strike women and men equally - and it is certainly 
reasonable to say that disadvantage begets gendered disadvantage when downturns occur (Cook and Powell 2010). Women are disproportionately among the most disadvantaged and with age even greater hardships accrue to them. Adding to the intricacies of these unparalleled changes is the velocity with which they are taking place and the fact that they are accompanied by a deepening division between those whose principal pursuits are in subsistence or service sector markets and their counterparts who are primarily involved in large-scale export, international sectors, or equity markets. Together these forces are bringing about a profound imbalance within and between populations as one group shares in the generation of wealth while the other becomes increasingly dependent and is being subordinated to decisions made in the other sector, by a cartel half a world away (Bauman, 1998).

This is not to say that states are mere minions of transnational interests but it is no longer the case that nationstate sovereignty can be taken-for-granted in the policy realm. Nor is it necessarily the case that state policies are as all-powerful as they once were in shaping daily life (Dallmayer, 2005; Fraser, 2005). As Evans and Cerny (2004) so cogently assert, the welfare state of the last century has been replaced by a competitive state of the 21 st century, always mindful of its global positioning (see also, Hudson \& Lowe, 2004). Foucault (1978) coined the phrase "nonsovereign power" when he was discussing issues of bodily control. By drawing a nice analogy Yapa (2002:15) proposes that a parallel concept may provide insights into the vagaries of post-industrial public-sector decision making. To make sense of domestic versus international priorities and their effect on daily life, scholars would do well to come to terms with the notion of "non-sovereign power" as it applies to social justice, autonomy, monetary policies and capital mobility, and other forms of extra-national pressures emending local policies. We would assert that to date there has been a real lag between transnational developments and the way analysts think of social policies. Appadurai (2001) attributes the stumbling blocks in conceptualization to "...the disjunctures between various vectors characterizing this world-in-motion that produce fundamental problems of livelihood, equity, suffering, justice, and governance" (Appadurai, 2001: 6). In his characterization, proximate social issues have causes that are hardly local and call for non-parochial perspectives if they are to be addressed.

As Giddens maintains, one of the most significant impacts of globalization is that it has brought an "intensification of worldwide social relations which link distant localities in such a way that local happenings are shaped by events occurring many miles away and vice versa" (Giddens, 1990:64). As a consequence, few governments are eager to make decisions separately from their reliance on global enterprise; it is as though they are in a situation of shared sovereignty, having to negotiate between domestic, international, corporatist and transnational interests (EspingAndersen, 1990; Hill, 2006; Kennett, 2001; Navarro, 2007). NGOs such as the World Bank and the International Monetary Fund have also become architectural partners in local policy deliberations by sanctioning preferred welfare policies as a condition of their support of monetization (Deacon, Hulse, \& Stubbs, 1997; Dembele, 2007; Hart, 2002). Even so, nation-states nonetheless serve important administrative functions in a world dominated by transnational corporate interests and it is unlikely that governmental responsibilities are either going to be usurped or allowed to wither in light of their functionality (Hill, 2006; Navarro, 2007). It is not too far fetched to say that certain transnational interests see themselves as having universal jurisdiction, assertions of state autonomy notwithstanding.

With the spreading of these transformations has come a reshuffling of local priorities, with governmental emoluments directed or redirected to areas defined as having the greatest public importance and bringing the greatest returns. Of course the realities behind that assertion are deserving of close scrutiny as the policy process is unquestionably political and the state must mediate rival claims as it serves as the principal mechanism by which revenues are collected and resources distributed. Meanwhile, social entitlements, expenditures and daily experience for people who may not fully grasp the raison d'être behind their situations reflect these same priorities. Hill (2006) suggests that social policy regimes are regularly structured to be consistent with other forms of social stratification within a country. To the extent there is a convergence in social welfare policies around the globe it might not be mere coincidence that social stratification and social class divisions are growing more pronounced in the face of globalization. In light of global economic flows, the salience and permeability of national borders, whether in Europe, the western hemisphere, or in the East are a different matter than they were even half a century ago (Kearney, 1995).

In terms of both economics and domestic social policies, the impact of international economic relations has recontoured the landscape, so to speak, all the way to the regionalization and appropriation of economic relations. What were once bold lines of demarcation are now dotted lines more suggestive of administrative spheres than jingoistic borders. In the global century, deregulated markets are tightly integrated with political and social transformations, affecting local circumstances and communality (Geetz, 1973). All in all, the globalizing influences 
of the early 21 st century are producing a distinctive era in social history linked to the emergence of transnational actors as well as economics and technologies that are helping fuel the shifts. Global economic change portends more than alterations in per capita income, the nature of financial products and currency markets, or the rapid circulation of goods, communication or technologies. It is precursor to broad cultural and political shifts that challenge precontact arrangements, notions of social justice and solidarity, as well as local interaction patterns. In a post-modern world, globalization is creating interlocking dependencies linked to the ways in which priorities are ordained by transnational interests. As Chen and Turner (2006) point out in a discussion focused on the welfare of the elderly but equally applicable to all social welfare, the accrual of public benefits reflects the invisible hand of market forces, the invisible handshake of tradition and the invisible foot of political decisions. Despite avowals about the secularity of modern life, economic-thinking, what might be termed spreadsheet logic is accorded near theological status, its canons seen as universally applicable and providing appropriate precept for adjudicating what is considered fair and just. These tendencies are abetted by what is sometimes called the cyber infrastructure, or more simply, informatics, reinforcing these shifts and creating a digital divide separating those on either edge of the diffusion of innovations. Of course there is more to this technological transformation than the appearance of new ways to communicate, it has also paved the way to a post-fordist formulation that Castells (2000) labels network capitalism.

\section{| Globalization and the Social Contract}

We do not mean to imply that globalization comes as a unified package; it is nonetheless true that major changes have resulted from an ability to move capital around as summarily as desired to gain leverage, possibly destabilizing local financial and labor-markets in the process. Real questions have emerged about the autonomy of nation-states and the balancing of altruistic social expenditures with economic participation on the world stage. The tensions between social protections and global corporate connections are contributing to what can aptly be called "social deficits" in which people are left to fend for themselves to the extent that they are able. In the face of inflation and related economic adversities, slashing social spending is routinely offered as a fitting resolution preferable to raising taxes for wealthy individuals or corporations (Mishra, 1999). The global span of information technologies and the advent of the global compass held by transnational corporations means they are able to shift extraction, manufacturing, fabrication and many service functions to whatever locale offers the most favorable economic returns, including tax structures. These and other consequences of globalization are fraught with new risks and ambiguities in daily experience and in the way matters of worth are defined; along with the many positive aspects that are undeniably part of the process associated with privatization.

In a synopsis of a few of the more evident effects of globalization, Navarro (2007) points to the privatization of services, public assets and other public provisions in asymmetrical fashion; deregulation of labor and currency markets as well as other forms of commerce; free trade; escalation of an accompanying anti-interventionist rhetoric; encouragement of individualism and consumerism. A number of commentators have noted that a corollary of globalization results in an unprecedented pattern of social risk. As Townsend (2007) so elegantly points out, the globalization of the marketplace is changing the face of dependency. It is as though the configuration of risks has shifted from settling on just those poor, down and outers living along society's margins to those derailed by restructuring of labor markets, the dramatic spread of employment in service sector jobs, shifts in the types of career patterns that so characterized the 20th century and the role of informatics affecting employability of middle-class workers.

These risks are not grounded merely in the absence of resources but in an absence of personal autonomy and by people's position relative to others. Add to these factors the fact that as they wrestle with the issues, national and local governments are assailed from multiple fronts: pressed by transnational interests to provide open trade liberalization for private enterprise and pressed by the growing need for social protections and labor policies to sustain the working populace and those whose lives have fallen through the proverbial social safety net. Ever more inclusive protections call for targeted expenditures at exactly the time when expenditures are hemmed-in by capacity to levy taxes of any type but especially progressive taxes and by powerful interested constituencies. The neoliberal globalizing drive has disenfranchised workers and their representatives in ways that have eroded their ability to bargain for benefits. Many commentators have noted that governments have generally adopted a laissez faire stance when for one reason or another they have chosen not to intervene in the disempowerment of the citizenry (Navarro, 2007). 
As a facet of a much broader movement toward privatization, governmental social services are adopting a marketbased management model and relying on non-governmental agencies (NGOs) to take up the slack. There is a wide array of subtypes and expenditure patterns associated with every form but an underlying logic in nearly all instances is a push toward commodification or cost-effectiveness of the programs (couched in terms of return on investment measured by market-driven stipulations), in contrast to their ability to genuinely affect lives. Policy recipients not likely to provide economic returns on governmental investments in them tend to be defined as burdensome charity cases. There are extensive changes that may be adapted to local contextual factors reflecting long-standing norms, values, religions, policies, existing social metrics and institutionalized arrangements even as they embody overtones imposed by international priorities (Dallmayer, 2005; Fraser, 2005). Unraveling the relative importance of domestic arrangements and transnational influences can be a tricky task, to say the least. It involves both an in-depth grasp of domestic issues and an international perspective, an awareness of transnational forces impinging on local decisions and sophisticated methodological and theoretical frameworks.

The commodification of social services, as it is sometimes called, is abetted by a transfer of issues of citizenship to a forum which is no longer native in its scope but transnational; marked by intergovernmental structures, multinational corporate influence and population changes (Ascoli and Ranci, 2002; Phillipson, 2006:202). There is another layer of complexity added by a worldwide tendency to view a number of social issues through a medical lens (e.g., Kutchins \& Kirk, 2003) and the insecurities experienced by the citizenry in general are without parallel in world history. What might be described as apodictic, self-evident truths of tradition tend to lose their currency and help demarcate generational and participatory categories from one another.

In the face of an unswerving drive to be players on the world's stage, enhance market share and survive economic rip-tides, nation-states must balance the demands of competing claimants - leaving them few options but to make hard choices. Not only do they have to adjudicate where to put scarce resources and which groups are deserving of protection or support, but few actions are indemnified against the next economic shortfall meaning they will have to review their priorities anew each time the economic tides turn. It has always been true that in times of plenty promises about solutions to societal woes are an easy pledge to make; during times of scarcity it is a different story and keeping even the best-intentioned promises oftentimes creates real conflicts. Societal-level redefinitions of what is fair and just are a common means to solutions that do not always do well by citizens in need of assistance, undermining personal sense of security and identity as well as social solidarity (Powell, 2010).

An illustration of a macro-level problem may be helpful for thinking about the type of quandary involved. As nation-states undergo economic development via participation in global commerce, per capita incomes generally increase, never mind for the moment internal disparities, life expectancies increase and demands for healthcare mount. Continued change and desires to remain viable in the global economy mean a country will face enduring challenges in providing social safety nets, medical interventions or financing health care protections. To focus on just the health care issue: despite subsidized provisions for indigent citizens, most healthcare coverage around the world is linked to employment and economic productivity (workfare) and as employment is destabilized so too is healthcare. Needless to say, employment-based systems are costly, leading to cost shifting which also serves to grant license to employers to cut jobs and move production around to minimize the expense of doing business (ironically, economic reform in former socialist countries took the same direction, e.g., Chen, 2004). For those not covered by employment-based plans, subsidized coverage is oftentimes available but financed by taxes and premiums or by governmentally mandated insurance groups saddled with high expectations and expenditures. But social policies supportive of indigent care for those not involved in economically productive activities are often singled out as a cost sink and are among the first issues put on cost-cutting agenda (Jessop, 2002).

In order to comprehend the underpinning of certain forms of inequalities it is also important to examine some of the transformations that are altering people's lives. One post-modernist reality of the 21 st century is the existence of a digital divide between those who have always known how to navigate in key-stroke technologies and those "ancients" who learned it later or not at all. Those who are comfortable with the technology have the world at their fingertips and no longer depend on local relationships or role models for solace or validation. The result is an indisputable social segmentation. Whatever norms of reciprocity had existed before are likely to falter and fray under the impact of interdicting worldviews in which the deep grammar of sociability is no longer meaningful to those versed in the newer modes of activity. At the same time, there is an erosion of communities of like minds with shared representations cutting across society at large and fostering social solidarity. Instead they are replaced by segmented, smaller communities and a blurring of ways of knowing the world. Beck, Bonass and Lau (2003: 
6) characterize the effects of technological innovation as "revolution through side effects" and suggest a deepseeded societal segmentation is a likely upshot and should not be surprising. Addressing comparable consequences, Dasgupta (2006:159) phrased it succinctly: "globalization has thus created an identity crisis, since many are neither local nor global and are overloaded with changing stimuli... resulting in a 'don't care' attitude, commercial interactions among family members, a rise of individualism and a disequilibrium...."

Transnational private enterprises cannot be ignored as they are altering the landscape but they are not doing so single-handedly. It is fair to say there are both private and semi-public but non-governmental organizations (NGOs) involved. Multilateral NGOs are playing an especially crucial role and certainly a role that is influencing developing countries as they sort out their welfare regimes. For example, since the issuance of the Berg Report in 1981, the World Bank and the International Monetary Fund (IMF) have become major players on the world's stage oftentimes stipulating structural adjustments and preferred policies nation-states should adopt as a condition of support and in order to attract direct capital investments or other fiscal cooperation, including monetization. One illustration is that the World Bank began urging diminutions in pay-as-you-go (PAYG) pension provisions in favor of means-tested pensions and private provisions in the mid-1990s. The World Bank and the IMF have been staunch advocates for over three decades for broadly defined market-led welfare policies as a preferred alternative to un- or under-funded public welfare (Dembele, 2007; Wade, 2007). Encapsulating both the criticisms and the confluence of forces fueling such a movement, McMichael (2000) asserts that the drive for economic integration pays precious little attention to nation-building, national interests or public sector regulatory control. As a consequence, even nonprofit, social enterprises tend to be "doing good badly" (Tekula, 2010).

Although there is a remarkable absence of consensus, social welfare is customarily taken to mean statutory governmental intervention designed to provide supportive services and resources to those in need. Right away one question that has to be addressed revolves around eligibility requirements and stipulations of entitlement. Such issues as gender are very much a part of the state, as are discussions of family responsibilities and welfare policies. At the risk of extreme simplification, whether women are eligible for social benefits and services in their own rights or as members of a male-breadwinner family is an abiding question whenever welfare regimes are examined. By the same token, gender ideologies are very much an aspect of poverty, labor markets and other market experiences, or the myriad inequalities that cut across the life course and through virtually every facet of experience (Calasanti, 2001; Hatch, 2000; Sainsbury, 1994; 1996).

These same forces also affect lives in even more subtle ways beyond the realm of income, access or protection. Just one case in point out of scores of similar situations should suffice to illustrate our contention. It is fair to say that institutional arrangements and structural realignments have altered time and temporality as they have altered space and other normative aspects of life. Containing our focus to the issues discussed thus far; the ebb and flow of transnational capital markets operate around the clock and penetrates virtually every aspect of governmental policy and, accordingly, daily life. Analysts generally concur that there has been a compression of time in many corners of the world as they are pulled into global market flows (Powell, 2010). As should be fairly obvious, any attenuation of earlier subjective temporal reckoning requires a recalibration and re-integration as new templates are incorporated into mental models of what life is about. Analysts have asserted that globalization brings a dilation, fragmentation and acceleration of the sense of time unsettling to many (Lestienne, 2000). But, as with so many other aspects of globalization, the results do not settle on all people in equal fashion. For those who live along the margins of such change, feelings of being in-control and the clarity of their proleptic futures may be challenged as the pace, and types of engagements in their lives are restructured. Considered in a broader sense, temporal reorganization is also impacting event timing and thereby the shape of life, views of dependency and definitions of personal worth. As normative perspectives on the shape of life are reformulated and/or personal functionality wanes, the chances increase that some subgroups within the population will lose track of their referential guidelines (Moody 2006).

In her insightful analysis of German pension provisions, Scheiwe (1994) brings a fresh perspective to discussion of how institutionalized welfare rules also structure temporality. She broadens the focus considerably in her examination of time politics and gendered times in legislation that grants standing to many market-related definitions of time and discounts others associated most frequently with women's roles outside the market or which result from discontinuous market-related activities deemed to be below time thresholds written into public welfare provisions. The gendered differentials in recognizing life's events, their timing and related circumstances serve to create essential inequalities in financial and other types of well-being. Time and temporality, sense of the future, and eligibility for entitlements impose structure on lives in ways that may not have been intended but are highly salient, nonetheless. 
For the most part, a definition derived from the legendary Beveridge Report published in the midst of World War II in Britain has been utilized to identify and operationalize major features of the welfare state (Finer, 1999). Yet that formulation begs the question of whether that world and those circumstances still exist and how they may have been modified by post-industrial or globalizing influences. We would assert that a definition of social welfare must extend beyond questions of delivery to include its financing and function. Almost certainly the provision of non-governmental services through NGOs or volunteer agencies and programs should be included as well. Ambiguities not withstanding, it is hardly surprising that scholars looking at social welfare in a comparative focus have noted that there is a fairly direct correlation between national prosperity and percentage of GDP directed at supportive programs (Hill, 2006). However, within groups of nations (such as OECD, G-8, or G-20 countries) there are differences based on governmental types or economic developments and, we assert, in terms of underlying principles of moral economy that have shaped the formulation of welfare, whether that be public or private.

\section{Conclusion}

Inequality is an outstanding issue in the study of post-industrialism while globalization has widened its consequences such as planetary poverty and gender stratification. The potential reasons lie in the reformulation of economic power associated with burgeoning free-market economies and accompanying diffusion of instrumental rationality, standardization, commoditization or secularism. In contrast with the economic downturn and global softening of labor markets which cry for greater social protection, the welfare state of the last century has been replaced by a competitive state of the 21 st century, as a "non-sovereign power" mindful of its global positioning but less powerful in shaping daily life among social forces including the role of NGOs. However, nation-states still serve important administrative functions in a world dominated by transnational corporate interests. With few options and having to make hard choices, welfare provision has seen trends toward commodification of social services while globalization is affecting social contracts as well. In the face of all these challenges to justice and governance, there must be a twin track approach: social welfare needs to be redefined and extended while market economy must be guided by moral principles that embody fundamental human values.

\section{References}

Annual World Wealth Report (2008). 12th Annual World Wealth Report. New York: Merrill Lynch/ Capgemini.

Appadurai, A. (2002). Grassroots globalization and the research imagination. In A. Appadurai (Ed.). Globalization (pp. 1-21). Durham, NC: Duke University Press.

Arias, A. O., \& Logan, B.I. (2002) Conclusion: From globalization towards universalization in the twenty-first century. In B. I. Logan (Ed.). Globalization, the third world state and povertyalleviation in the twenty-first century (pp.197-202). Aldershot, $\mathrm{UK}$ : Ashgate.

Ascoli, U., \& Ranci, C. (2002). The context of new social policies in Europe. In U. Ascoli \& C. Ranci (Eds.). Dilemmas of the welfare mix: The new structure of welfare in an era of privatization(pp. 1-24). New York: Kluwer Academic/Plenum Publishers.

Bauman, Z. (1998) Globalization: The human consequences. New York: Columbia University Press.
Beck, U. (1999). World risk society. Cambridge: Polity Press.

Beck, U., Bonss, W. \& Lau, C. (2003). “The theory of reflexive modernization: Problematic, hypotheses and research programme." Theory, Culture \& Society, 20, 1-33.

Calasanti, T. M. (2001). Gender, social inequalities and aging. Walnut Creek, CA: AltaMira.

Castells, M. (2000). The rise of the network society: The information age: Economy, society and culture, Volume 1 (2nd edition). Oxford, UK: Blackwell.

Chen, S. (2004). Public Policy and Development Strategy: Theoretical, Comparative, and Historical Perspectives Illustrated with the Case of the Chinese State. Dubuque, IA: Kendall/Hunt Publishing

Chen, S., \& Ravallion, M. (2007). The Changing Profile of Poverty in the World. 2020 FOCUS BRIEF on the World's Poor and Hungry People. Washington, D.C.: International Food Policy Research Institute. 
Chen, Y-P., \& Turner, J. (2006). Economic resources: Implications for aging policy in Asia. In H. Yoon \& J. Hendricks (Eds.). Handbook of Asian Aging (pp. 67-90). Amityville, NY: Baywood.

Cerny, P. G., \& Evans, M. (2004). Globalisation and public policy under new labour. Policy studies, 25, 51-65.

Clark, G. (2007). A farewell to alms: A brief economic history of the world. Princeton, NJ: Princeton University Press.

Cook, I and Powell, J (2010) Aging in Asia. New York: Nova Science Publishers

Dallmayer, F. (2005). Small Wonder: Global Power and its Discontents. Lanham, MD:Rowman \& Littlefield.

Dasgupta, S. (2006). Globalization and its future shock. In S. Dasgupta \& R. Kiely (Eds.), Globalization and after (pp. 143-183). Thousand Oaks, CA: Sage.

Deacon, B., Hulse, M., \& Stubbs, P. (1997). Global social policy: International organizations and the future of welfare. Thousand Oaks, CA: Sage.

Dembele, D. M. (2007). The International Monetary Fund and the World Bank in Africa: A disastrous record. In V. Navarro (Ed.), Neoliberalism, globalization and inequalities: Consequences for health and quality of life (pp. 369-377). Amityville, NY: Baywood.

Esping-Andersen, G. (2002). Why we need a new welfare state. Oxford: Oxford University Press.

Esping-Andersen, G. (1990). Three worlds of welfare capitalism. Cambridge: Polity Press.

Finer, C. (1999). Trends and developments in welfare states. In J. Clasen (Ed.). Comparative social policy: Concepts, theories and methods (pp. 15-33). Oxford: Blackwell.

Foucault, M. (1978). The history of sexuality. New York: Pantheon Books.

Fraser, N. ( 2005).Transnationalizing the public sphere. In M. Pensky (Ed.), Globalizing Critical Theory(pp. 37-47). Lanham, MD: Rowman \& Littlefield.

Geertz, C. (1973). The Interpretation of Cultures. New York: Basic Books.

Giddens A. (1990). The Consequences of Modernity. Cambridge: Polity Press.

Hart, G. (2002). Disabling globalization: Places of power in postapartheid South Africa. Berkeley, CA: University of California Press.

Hatch, L. R. (2000). Beyond gender differences. Amityville, NY: Baywood.

Hendricks, J. (2005). Moral economy and aging. In M. L. Johnson (Ed.). Cambridge handbook of age and ageing (pp. 510-517). Cambridge: Cambridge University Press.
Hill, M. (2006). Social policy in the modern world. Oxford: Blackwell.

Hoogvelt, A. (1997). Globalization and the postcolonial world: The new political economy of development. Baltimore, MD: Johns Hopkins University Press.

Hudson, J., \& Lowe, S. (2004). Understanding the policy process: Analysing Welfare policy and practice. Bristol, UK: Polity Press.

Jessop, B. (2002). The future of the capitalist state. Bristol, UK: Polity Press.

Kearney, M. (1995). The local and the global: The anthropology of globalization and transnationalism. Annual Review of Anthropology, 24: 547-565.

Kennett, P. (2001). Comparative social policy. Buckingham: Open University Press.

Kutchins, H., \& Kirk, S. A. (2003). Making Us Crazy - DSM: The Psychiatric Bible and the Creation of Mental Disorders. New York: Free Press.

Lestienne, R. (2000). Time and globalization: does the emergence of a global identity entail a loss of individualities. Time and Society, 9, 289-291.

Mabbett, D., \& Bolderson, H. (1999). Theories and methods in comparative social policy. In J. Clasen (Ed.). Comparative social policy: Concepts, theories and methods (pp. 34-56). Oxford: Blackwell.

McMichael, P. (2000). Development and social change. Thousand Oaks, CA: Pine Forge Press.

Mishra, R. (1999). Globalization and the welfare state. Cheltenham, UK: Edward Elgar.

McMichael, P. (2000). Development and social change. Thousand Oaks, CA: Pine Forge Press.

Navarro, V. (2007). Neoliberalism as a class ideology; or, the political causes of the growth of inequalities. In V. Navarro (Ed.), Neoliberalism, globalization and inequalities: Consequences for health and quality of life (pp. 9-23). Amityville, NY: Baywood.

Phillipson, C. (2006). Ageing and globalization. In J. Vincent, C. Phillipson, \& M. Downs (Eds.). The futures of old age (pp. 201-207). Thousand Oaks, CA: Sage.

Powell, J and Cook, I.G. (Eds.) (2010) Aging in Asia. Nova Science: NY

Powell, J (2010) Aging, Theory and Globalization. Nova Science: NY

Sainsbury, D. (1996). Gender equality and welfare states. Cambridge: Cambridge University Press.

Sainsbury D. (Ed.). (1994). Gendering Welfare States. Thousand Oaks, CA: Sage. 
Scheiwe, K. (1994). German pension insurance, gendered times and stratification. In D. Sainsbury (Ed.). Gendering Welfare States (pp. 132-149). Thousand Oaks, CA: Sage.

Shalev, M. (2007). Book review of G. J. Kasza One world of welfare: Japan in comparative perspective. In American Journal of Sociology, 112, 905-907.

Steger, M. B. (1997). The future of globalization. In A. D. King (Ed.). Culture, globalization and the World-System (pp. 116-129), Minneapolis, MN: University of Minnesota Press.

Tekula, Rebecca (2010). Social Enterprise: Innovation or Mission Distraction? Working Paper, Helene and Grant Wilson Center for Social Entrepreneurship, Pace University.
Townsend, P. (2007). Using human rights to defeat ageism: Dealing with policy-induced 'structured dependency.' In M. Bernard \& T. Scharf (Eds.), Critical perspectives on ageing societies (pp. 27-44). Bristol, UK: Polity Press.

Wade, R. H. (2007). The causes of increasing world poverty and inequality; or, what the Matthew Effect prevails. In V. Navarro (Ed.), Neoliberalism, globalization and inequalities: Consequences for health and quality of life (pp. 119-141). Amityville, NY: Baywood.

Yapa, L. (2002). Globalization and poverty: From a poststructural perspective. In B. I. Logan (Ed.). Globalization, the third world state and poverty-alleviation in the twenty-first century (pp.15-29). Aldershot, UK:Ashgate. 
